$\mathbf{R}_{\text {ESEARCh }} \mathbf{P}_{\text {APER }} \longrightarrow$ FOOD SCIENCE RESEARCH JOURNAL
ISSN-0976-1276 - Visit us : www.researchjournal.co.in Volume $11 \mid$ Issue 2 | October, $2020 \mid$ 158-168 DOI : $10.15740 / \mathrm{HAS} / \mathrm{FSRJ} / 11.1 / 158-168$

\title{
Development of jackfruit leather and its shelf-life analysis in different packaging materials
}

\begin{abstract}
Ninisha Babu, Ammu Dinakaran, Maya Raman, Akshaya Ravindran, T.V. Sankar and T. K. Srinivasa Gopal
Post-harvest loss is very common in seasonal fruits due to its high perishability even under refrigerated conditions. Value addition and processing is the best solution to overcome this problem and it also ensures the availability of the product round the year. This study is to develop jackfruit leather that replicates the natural fruit taste and is shelf stable at room temperature $\left(28 \pm 2^{\circ} \mathrm{C}\right)$. The product contributes $3.63 \mathrm{Kcal} / \mathrm{g}$ to the energy requirement and is rich in minerals like potassium and sodium $(7442 \mu \mathrm{g} / \mathrm{g}$ and $1842 \mu \mathrm{g} / \mathrm{g}$, respectively). Sorption isotherm studies showed a sigmoid characteristic for the product. It has a critical moisture content of $48.39 \pm 0.44 \%$ with respect to $96 \%$ relative humidity and a water activity of 0.47 . The product was packed in different packaging materials like 220 -gauge polyethylene laminated with 50 -gauge metalized polyester (Met PE) and 150 gauge Biaxially Oriented Poly Propylene (BOPP) laminated with 50-gauge polyester to study and compare its shelf-life in both the packaging materials at room temperature $\left(28 \pm 2^{\circ} \mathrm{C}\right)$. Physical and chemical parameters of the product was analyzed during the period of storage and the results revealed a shelf stability for 90 days for the product packed in both the packaging materials.
\end{abstract}

Key Words : Jackfruit leather, Value addition, Sorption isotherm, Water activity, Shelf- life

How to cite this article : Babu Ninisha, Dinakaran, Ammu, Raman, Maya, Ravindran, Akshaya, Sankar, T.V. and Srinivasa Gopal, T.K. (2020). Development of jackfruit leather and its shelf-life analysis in different packaging materials. Food Sci. Res. J., 11(2): 158168, DOI : 10.15740/HAS/FSRJ/11.2/158-168.Copyright@ 2020: Hind Agri-Horticultural Society.

Email: ammu.dinakaran@gmail.com

Associate Authors' :

Ninisha Babu, Maya Raman, Akshaya Ravindran, T.V. Sankar

and T.K. Srinivasa Gopal, enter of Excellence in Food Processing

Technology, Kerala University of Fisheries and Ocean Studies,

Panangad, Madavana (Kerala) India 